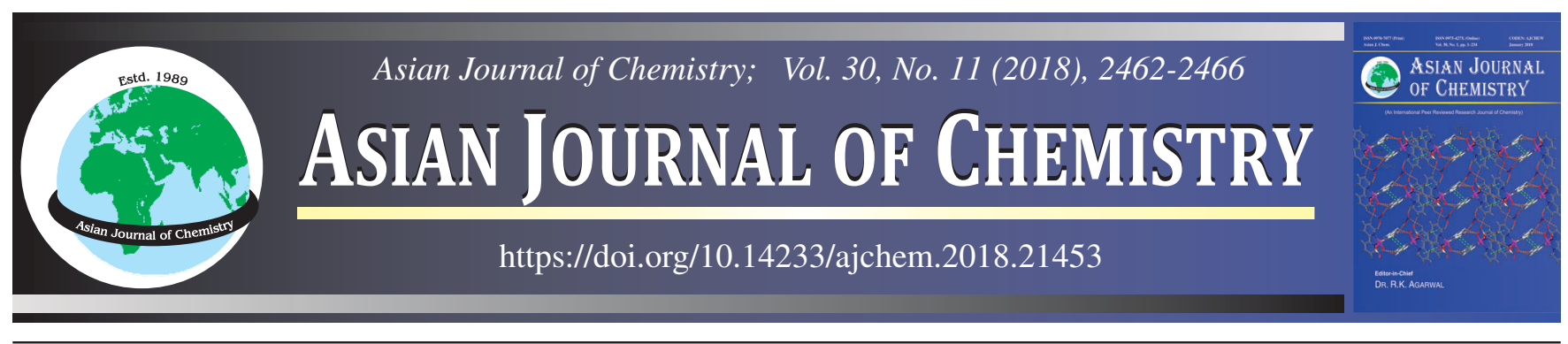

\title{
Evaluation of Adsorption Capacity of Prosopis juliflora Seed Powder for Removal of Trace Elements from Aqueous Solution
}

\section{SANGU* and S.P. PRIYADHARSHINI}

Department of Chemistry, Cauvery College for Women, Tiruchirappalli-620 018, India

*Corresponding author: E-mail: venkatasangu@ gmail.com

Received: 17 May 2018;

Accepted: 14 June 2018;

Published online: 27 September 2018;

AJC-19095

In this present study Prosopsis juliflora seed powder has been tried out as an economically efficient adsorbent to remove $\mathrm{Cd}(\mathrm{II}), \mathrm{Cu}(\mathrm{II})$ and $\mathrm{Zn}$ (II) from aqueous solution. FTIR analysis of compounds present in Prosopsis juliflora seed powder have -OH, C-N str, C=O, -NH alike functional groups. These functional group were responsible for binding of heavy metal in wastewater on Prosopsis juliflora seed powder. SEM morphological study shows Prosopsis juliflora seed powder poses rough surface. Hence, heavy metals in wastewater are easily absorbed on the surface of the seed powder. The influence of various process parameters such as solution $\mathrm{pH}$, sorbent dose and contact time on the removal process for removing $\mathrm{Zn}, \mathrm{Cu}$ and $\mathrm{Cd}$ from wastewater were investigated by batch mode of operation. The percentage removal of $\mathrm{Cd}(\mathrm{II}), \mathrm{Cu}(\mathrm{II})$ and $\mathrm{Zn}(\mathrm{II})$ were found to be 88,90 and $85 \%$ at optimum $\mathrm{pH}$ and contact time and sorbent dosage. Freundlich and Langmuir adsorption isotherm were drawn for varying initial concentration of $\mathrm{Cd}(\mathrm{II}), \mathrm{Cu}(\mathrm{II})$ and $\mathrm{Zn}$ (II) ions. Straight-line nature of the plots indicated that the adsorption process follow both isotherm model. The adsorption capacity $\left(\mathrm{Q}_{0}\right)$ values for the removal of $\mathrm{Cd}(\mathrm{II}), \mathrm{Cu}(\mathrm{II})$ and $\mathrm{Zn}(\mathrm{II})$ were found to be $52.63,43.47$ and $35.71 \mathrm{mg} / \mathrm{g}$, respectively.

Keywords: Prosopsis juliflora, Adsorption, Freundlich isotherm, Langmuir isotherm.

\section{INTRODUCTION}

Presence of heavy metals in the wastewater has been of great concern because of increasing discharge, toxic nature and other adverse effects on receiving bodies of water. Major sources of heavy metals to the water is rapidly developed industries like metal processing, paper pulp industry, fertilizer industry, batteries, etc. discharge heavy metals contaminant into nearby water bodies [1]. Adsorption is emerging out as one the best method to remove heavy metals from wastewater on behalf of its low operational cost and its efficiency to remove even trace amount of heavy metal contaminant from wastewater. Numerous cost effective, easily available plant materials have been tried out for removing heavy metal from wastewater [2].

Prosopis juliflora is an evergreen xerophytic tree. Prosopis juliflora tree bears pods in both summer and winter season. The seed contain biologically active compounds such as alkaloids, carbohydrates, flavonoids, amino acids, mucilage, cotyledon tannins and phenolic compounds. Lysine was the predominating amino acid in seeds and pods and methionine was present in small amount. Concentration of sulphur containing amino acids is low but the content of other amino acids is more [3]. Owing to the presence of many functional groups the Prosopis juliflora seed can be used as good adsorbents for removal of toxic metal ions in aqueous solutions. Moreover Prosopis juliflora plant is low-cost, abundantly available plant material. Hence, in the present work, Prosopis juliflora seed powder is used as inexpensive and effective adsorbent to replace commercially available adsorbent to remove heavy metals in wastewater.

\section{EXPERIMENTAL}

Preparation of adsorbent: Prosopis juliflora seeds are collected from local area. These seeds were dried under sunlight for a few days and then in oven at $80{ }^{\circ} \mathrm{C}$. The dried seeds were crushed and blended to powder form using a blender. Then the seed powder was sieved to the particle size of 300 to $800 \mu \mathrm{m}$ using ASTM.

Characterization adsorbent: FTIR spectroscopy was used to identify the functional groups present in seeds. The

This is an open access journal, and articles are distributed under the terms of the Creative Commons Attribution-NonCommercial 4.0 International (CC BY-NC 4.0) License, which allows others to copy and redistribute the material in any medium or format, remix, transform, and build upon the material, as long as appropriate credit is given and the new creations are licensed under the identical terms. 
samples were examined using Shimaduz 84005 FT-IRS spectrometer within range $4000-400 \mathrm{~cm}^{-1}$. Scanning electron microscope (SEM) (JOEL JSM 6360) machine was used to check the surface morphology of adsorbent prepared from Prosopis juliflora seed.

Preparation of metal ions solutions: A stock standard solution of $\mathrm{Cu}(\mathrm{II}), \mathrm{Zn}$ (II) and $\mathrm{Cd}(\mathrm{II})$ were prepared by dissolving appropriate amount of $\mathrm{CuSO}_{4} \cdot 5 \mathrm{H}_{2} \mathrm{O}, \mathrm{ZnSO}_{4} \cdot 7 \mathrm{H}_{2} \mathrm{O}$ and $\mathrm{CdSO}_{4} \cdot \mathrm{H}_{2} \mathrm{O}$ in double distilled water.

Batch experiment: The adsorption experiment was carried out in batch mode of operation at room temperature in 200 $\mathrm{mL}$ polythene bottles [4]. Each bottle contains $100 \mathrm{~mL} \mathrm{Cu}(\mathrm{II})$, $\mathrm{Zn}$ (II) and $\mathrm{Cd}$ (II) ion solutions of desired concentration (10 mg/L). $1.0 \mathrm{~g}$ of powdered Prosopis juliflora seed (PJS) adsorbent was added to each of the solutions and equilibrated for predetermined period. At the end of equilibrium period, the Prosopis juliflora seed powder was removed by filtration using Whatman filter paper (No. 41). The concentration of metal ions left out in of the solutions was analyzed by atomic absorption spectrophotometer. Effect of contact time on adsorption capacity of Prosopis juliflora seed for $\mathrm{Cu}$ (II), $\mathrm{Zn}$ (II) and $\mathrm{Cd}(\mathrm{II})$ ions in aqueous solution was determined at different time intervals (15 min) until the attainment of equilibrium.

Optimum sorbent dose for $100 \mathrm{~mL}$ the given concentration of (10 mg/L) $\mathrm{Cu}(\mathrm{II}), \mathrm{Zn}$ (II) and $\mathrm{Cd}(\mathrm{II})$ solutions was studied by varying adsorbent dosage from 1.0 to $5.0 \mathrm{~g}$. The effect of $\mathrm{pH}$ on adsorption capacity was studied by adjusting $\mathrm{pH}$ of $100 \mathrm{~mL}$ of $\mathrm{Cu}(\mathrm{II}), \mathrm{Zn}(\mathrm{II})$ and $\mathrm{Cd}(\mathrm{II})$ solutions congaing $1.0 \mathrm{~g}$ of Prosopis juliflora seed adsorbent to the required $\mathrm{pH}$ range (2-7) by adding $0.1 \mathrm{M} \mathrm{HCl}$ or $0.1 \mathrm{M} \mathrm{NaOH}$ solution.

Langmuir and Freundlich isotherm constants were determined for the adsorption of $\mathrm{Cu}(\mathrm{II}), \mathrm{Zn}(\mathrm{II})$ and $\mathrm{Cd}(\mathrm{II})$ on Prosopis juliflora seed powder. The percent adsorption of metal ions was calculated as follows:

$$
\text { Adsorption }(\%)=\left(\frac{\mathrm{C}_{\mathrm{i}}-\mathrm{C}_{\mathrm{e}}}{\mathrm{C}_{\mathrm{i}}}\right) \times 100
$$

Adsorption capacity at time $\mathrm{t}$ and at equilibrium in $\mathrm{mg} / \mathrm{g}$ were obtained as follow:

$$
\mathrm{q}_{\mathrm{e}}=\left(\frac{\mathrm{C}_{\mathrm{i}}-\mathrm{C}_{\mathrm{e}}}{\mathrm{m}}\right) \times \mathrm{V}
$$

where $C_{i}$ and $C_{e}(m g / L)$ are the initial and equilibrium concentration of metal ions, $\mathrm{V}$ was volume of the solution (L) and $\mathrm{m}$ is the mass of adsorbent $(\mathrm{g})$.

\section{RESULTS AND DISCUSSION}

Fourier-transform infrared spectroscopy (FTIR): FTIR analysis was used to identify the functional in Prosopis juliflora seed component, which are responsible for the adsorption of metal ions in aqueous solution. FTIR spectrum of Prosopis juliflora seed powder before and after adsorption of metal ions were compared (Fig. 1). Based on Fig. 1(a), a strong and broad band observed at $3300 \mathrm{~cm}^{-1}$ corresponds to stretching vibration of $-\mathrm{OH}$ group. The three distinct absorption bands located at 1653,1543 and $1237 \mathrm{~cm}^{-1}$ are assigned as amide $\mathrm{C}=\mathrm{O}, \mathrm{N}-\mathrm{H}$ and $\mathrm{C}-\mathrm{N}$ bands, respectively [5]. The vibration around 1401 $\mathrm{cm}^{-1}$ and $1447 \mathrm{~cm}^{-1}$ could be due to deformation vibration of
C-H group. Two discernible absorption bands at the wave numbers of $2926 \mathrm{~cm}^{-1}$ and $2874 \mathrm{~cm}^{-1}$ corresponding to alkyl groups [6]. These FTIR spectra of Prosopis juliflora seed powder after adsorption of metal ions shows [Fig. 1(b)-(d)] shift in adsorption frequencies. Change in absorption intensity and the shift in adsorption frequency of functional groups could be attributed to complexation between metal ions [Cu(II), $\mathrm{Zn}(\mathrm{II})$ and $\mathrm{Cd}(\mathrm{II})]$ and binding sites of Prosopis juliflora seed powder. Thus, metal ions in aqueous solution may be absorbed on Prosopis juliflora seed powder through these functional groups.

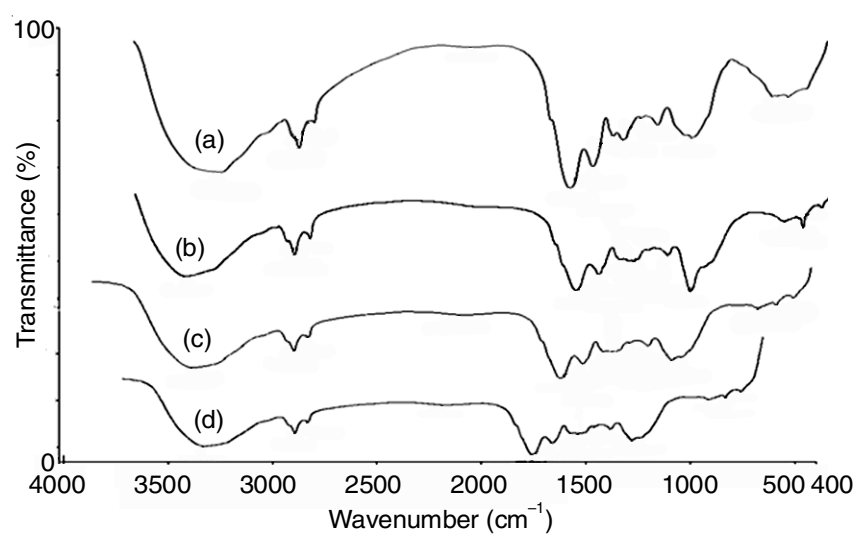

Fig. 1. FTIR spectra of Prosopis juliflora seed powder (a) before adsorption after adsorption of (b) $\mathrm{Cu}$ (II) (c) $\mathrm{Zn}$ (II) (d) $\mathrm{Cd}$ (II)

SEM analysis: Surface morphology of Prosopis juliflora seed powder was studied by SEM analysis. The SEM image of Prosopis juliflora seed powder, display a smooth and dense surface with small channels on the surface [Fig. 2(a)]. After adsorption of $\mathrm{Cu}(\mathrm{II}), \mathrm{Zn}$ (II) and $\mathrm{Cd}(\mathrm{II})$ ions, a significant change is observed in the surface of the adsorbent. Appearance of white dense (cloud) layer on SEM images [Fig. 2(a)-(b)], indicate metal ions were adsorbed on the surface of Prosopis juliflora seed powder.

Effect of contact time: Effect of contact time on adsorption efficiency of Prosopis juliflora seed powder of $\mathrm{Cu}$ (II), $\mathrm{Zn}$ (II) and $\mathrm{Cd}(\mathrm{II})$ ions were show in Fig. 3. It indicates that adsorption efficiency increases with increasing with increasing contact time until equilibrium is attained. Optimum contact time for the maximum removal of $\mathrm{Zn}$ (II) ion by Prosopis juliflora seed powder was found to be 120 . Whereas, optimum contact time for maximum removal of $\mathrm{Cu}$ (II) and $\mathrm{Cd}(\mathrm{II})$ ions were found to be $150 \mathrm{~min}$. Maximum percentage removal of $\mathrm{Cu}$ (II), $\mathrm{Zn}(\mathrm{II})$ and $\mathrm{Cd}(\mathrm{II})$ ions are 68, 66 and $72 \%$ at optimum $\mathrm{pH}$ and contact time.

Effect of pH: The $\mathrm{pH}$ of the solution is one of the important parameter which influence solubility of the metal ions, interaction of counter ion with the functional groups of the adsorbent and the extent of ionization of the of the adsorbate during adsorption. Hence, adsorption of $\mathrm{Cu}(\mathrm{II}), \mathrm{Zn}$ (II) and $\mathrm{Cd}(\mathrm{II})$ ions strongly depend on $\mathrm{pH}$ of the solution. Effect of $\mathrm{pH}$ on adsorption efficiency of Prosopis juliflora seed powder for $\mathrm{Cu}(\mathrm{II}), \mathrm{Zn}(\mathrm{II})$ and $\mathrm{Cd}(\mathrm{II})$ ions were shown in Fig. 4. An increasing $\mathrm{pH}$ of the solution from 2 to $6 \%$ removal of $\mathrm{Cu}$ (II) was found to be increases. In case of $\mathrm{Cd}(\mathrm{II})$ and $\mathrm{Zn}$ (II), the amount of metal ions adsorbed increased until $\mathrm{pH}$ 5.0. At low 

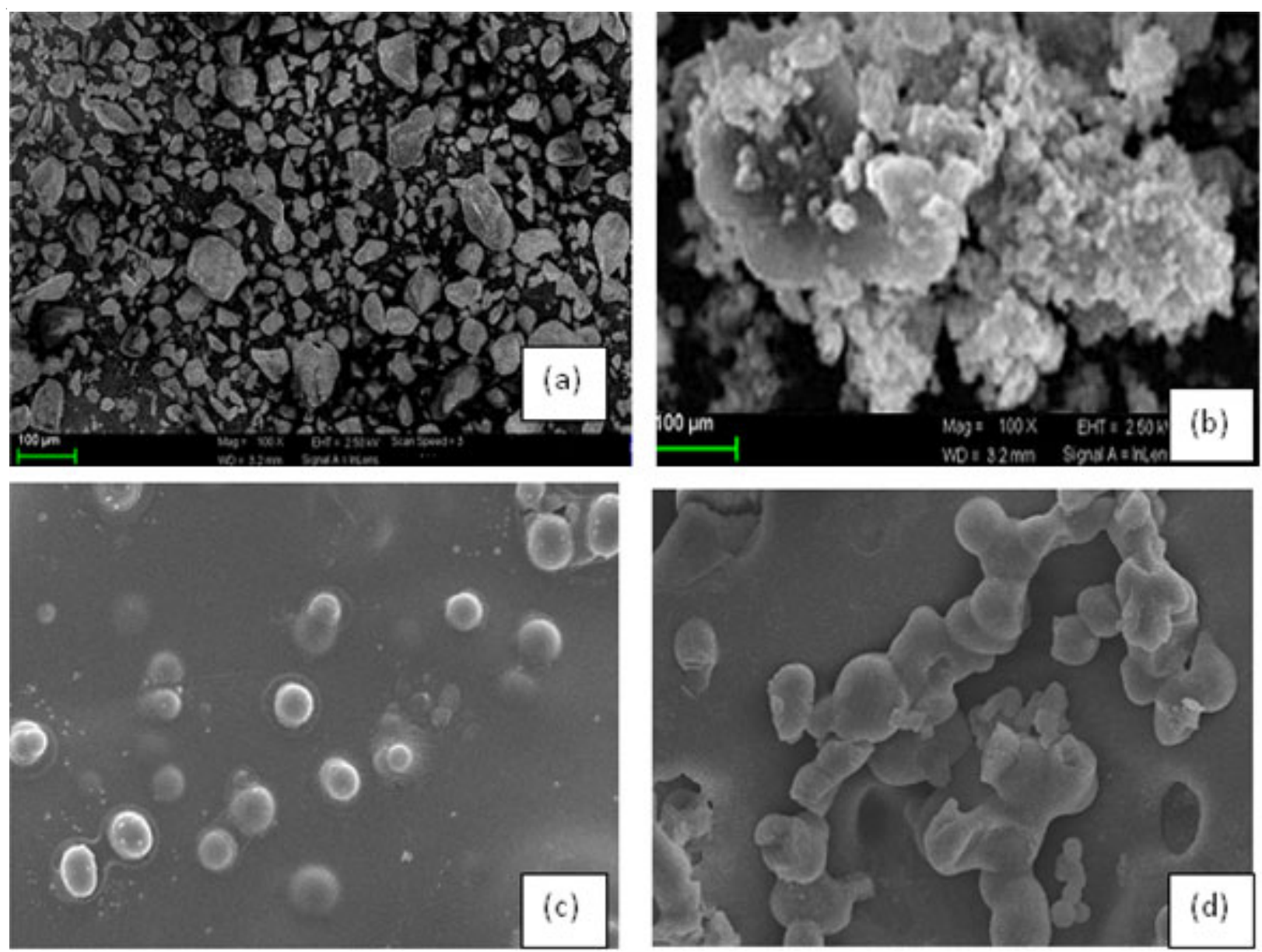

Fig. 2. SEM morphology of Prosopis juliflora seed powder (a) before adsorption and after adsorption of (b) $\mathrm{Cu}$ (II) (c) $\mathrm{Zn}$ (II) (d) Cd(II)

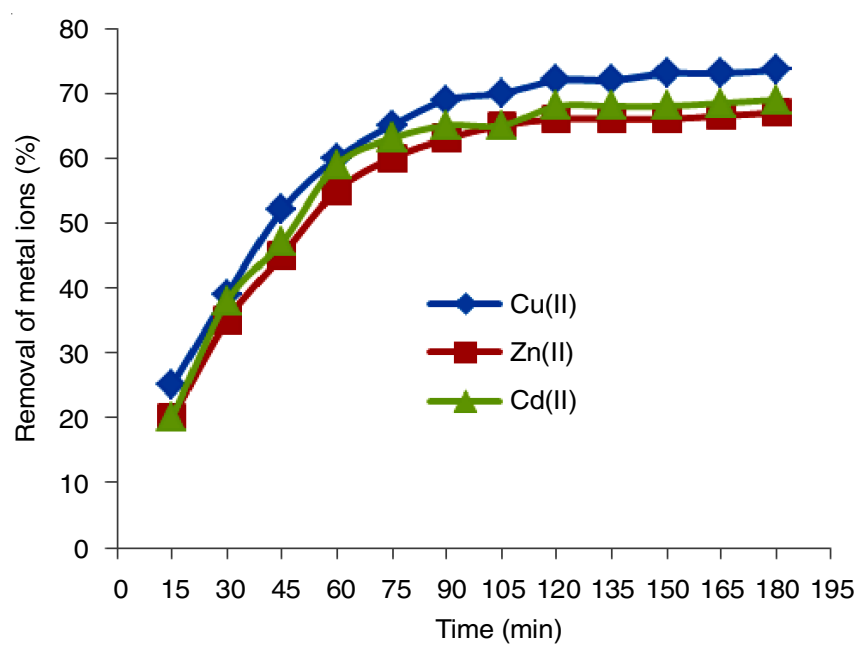

Fig. 3. Effect of contact time on adsorption

$\mathrm{pH}$, there is excessive protanation of active sites of the adsorbent and this refuse the adsorption of positively charged metal ions from solution. At moderate $\mathrm{pH}, \mathrm{H}^{+}$is released from active site of the adsorbent, therefore maximum amount of metal ions are adsorbed at this $\mathrm{pH}$ range of the solution. At higher $\mathrm{pH}$, the metal ions in aqueous solution get precipitated as metal hydroxides so adsorption capacity of Prosopis juliflora seed powder was found to be decreased at higher $\mathrm{pH}[7,8]$.

Effect of adsorbent dosage: Adsorbent dosage has a significant effect on percentage removal of metal ions in aqueous

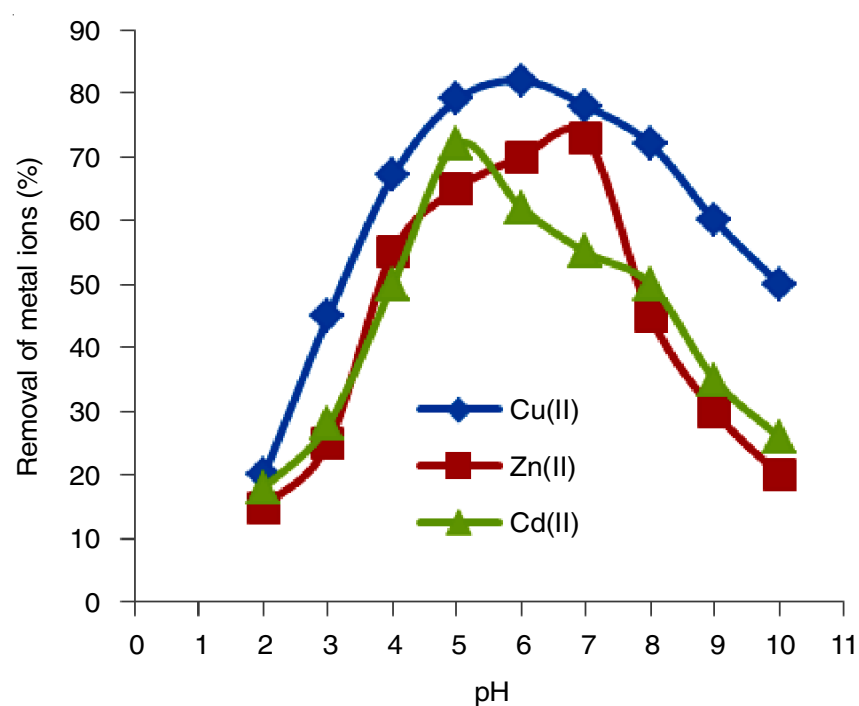

Fig. 4. Effect of $\mathrm{pH}$ on adsorption

solution. Effect of dosage of Prosopis juliflora seed on adsorption of $\mathrm{Cu}$ (II), $\mathrm{Zn}$ (II) and $\mathrm{Cd}$ (II) ions in aqueous solutions is shown in Fig. 5. Increasing adsorbent dosage increases percentage removal of $\mathrm{Cu}(\mathrm{II}), \mathrm{Zn}$ (II) and $\mathrm{Cd}(\mathrm{II})$ ions. Optimum dosage of adsorbent for maximum removal of $\mathrm{Cu}$ (II), $\mathrm{Zn}$ (II) and $\mathrm{Cd}(\mathrm{II})$ ions were found to be $3.0 \mathrm{~g}$. Further increase in adsorbent dosage did not increases percentage removal of metal ions. This may be due to the availability of excess adsorbent site for the metal ions [9]. 


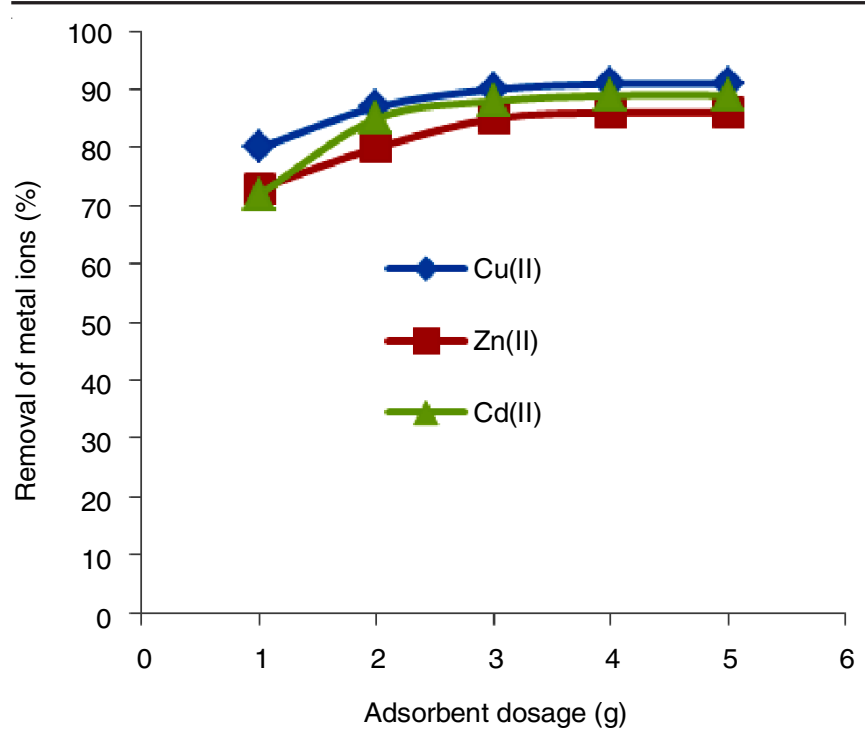

Fig. 5. Effect of adsorbent dosage

Adsorption isotherm: An adsorption isotherm model explains distribution of metal ions between solution phase and adsorbent surface. Isotherm studies were carried out by varying the concentration of $\mathrm{Cu}$ (II), $\mathrm{Zn}$ (II) and $\mathrm{Cd}(\mathrm{II})$ metal ions for the fixed amount of adsorbent $(1.0 \mathrm{~g} / 100 \mathrm{~mL})$. The experimental data for the adsorption of all the three ions were examined with Langmuir and Freundlich adsorption isotherms. Langmuir model is valid for monolayer adsorption onto the adsorbent having fixed number of adsorbent sites $[4,10]$.

$$
\text { Langmuir isotherm }=\frac{\mathrm{C}_{\mathrm{e}}}{\mathrm{q}_{\mathrm{e}}}=\frac{1}{\mathrm{Q}_{0} \mathrm{~b}}+\frac{\mathrm{C}_{\mathrm{e}}}{\mathrm{Q}_{0}}
$$

where $\mathrm{C}_{\mathrm{e}}$ and $\mathrm{q}_{\mathrm{e}}$ are amount of metal ion in remain solution $(\mathrm{mg} / \mathrm{L})$ and amount metal ion adsorbed on the adsorbent $(\mathrm{mg} / \mathrm{g}$ ) at the end of equilibrium time. The plot of $\mathrm{C}_{\mathrm{e}} / \mathrm{q}_{\mathrm{e}} v s . \mathrm{C}_{\mathrm{e}}$ give a straight line (Fig. 6), from the slop and intercept of the line adsorption capacity $\mathrm{Q}_{0}(\mathrm{mg} / \mathrm{g})$ and affinity of adsorption $\mathrm{b}$ $(\mathrm{L} / \mathrm{mg})$ could be calculated [8].

The Freundlich equation is an empirical expression, which encompasses the heterogeneity of the surface and the experimental distribution of the sites and their energies [11].

Freundlich isotherm: $\log (\mathrm{x} / \mathrm{m})=\log \mathrm{K}_{\mathrm{f}}+1 / \mathrm{n} \log \mathrm{C}_{\mathrm{e}}$

where $\mathrm{C}_{\mathrm{e}}$ is the equilibrium concentration $(\mathrm{L} / \mathrm{mg})$ and $\mathrm{x} / \mathrm{m}$ is the amount of metal ions adsorbed per unit mass of the adsorbent. $\mathrm{K}_{\mathrm{f}}$ and $\mathrm{n}$ are the Freundlich constants related to the adsorption capacity and the rate of adsorption, respectively [9].

Plot of $\log (\mathrm{x} / \mathrm{m}) v s . \log \mathrm{C}_{\mathrm{e}}$ gives a straight line (Fig. 7) with a slope of $1 / \mathrm{n}$ and $\log \mathrm{K}_{\mathrm{f}}$ is the intercept of $\log (\mathrm{x} / \mathrm{m})$ at $\log C_{e}=0$ [8]. According to Desta [12], a high value of $n(>1)$ means that adsorption is good over the entire concentration range studied while a small value of $n(<1)$ indicates that

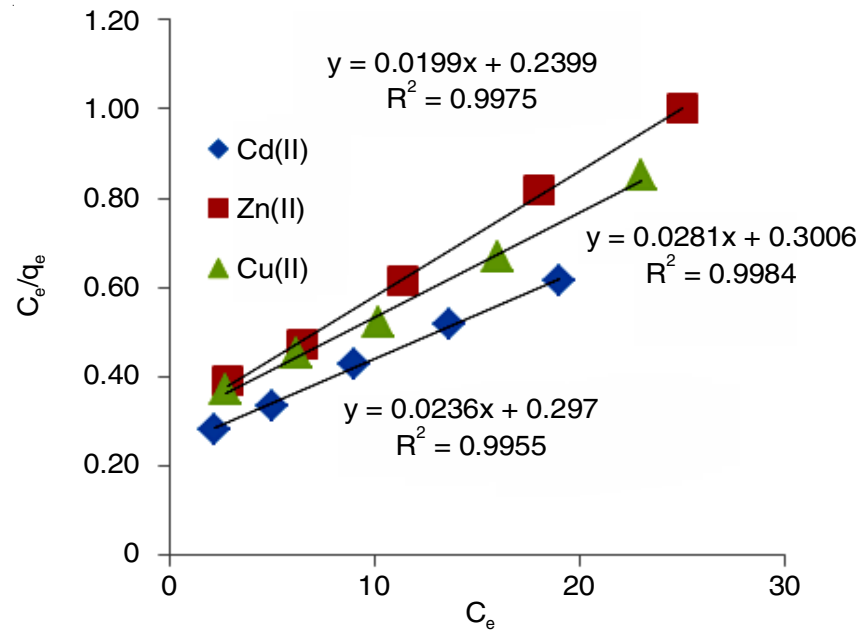

Fig. 6. Langmuir adsorption isotherms

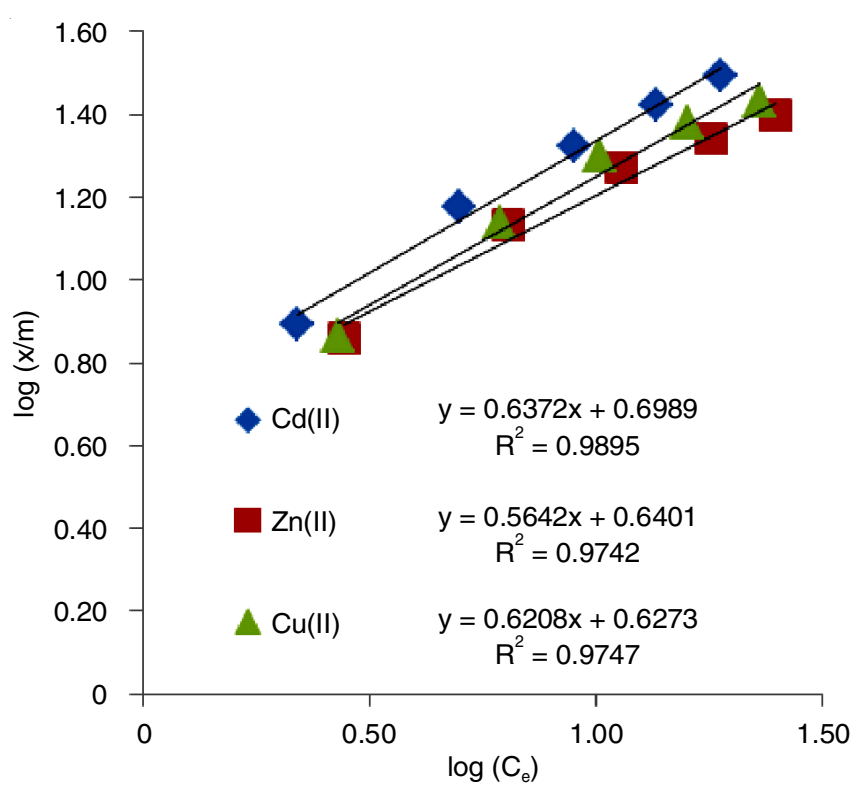

Fig. 7. Freundlich adsorption isotherm

adsorption is good at high concentrations and poor at low solute concentrations.

The calculated values of Freundlich and Langmuir isotherm constants are listed in Table-1. Langmuir isotherm model well fit to the experimental values with good correlation $\left(\mathrm{R}^{2}\right.$ values) for the adsorption of [Cu(II), $\mathrm{Zn}(\mathrm{II})$ and $\mathrm{Cd}(\mathrm{II})]$ metal ions onto the Prosopis juliflora seed powder. The maximum adsorption capacities $\left(\mathrm{Q}_{0}\right)$ estimated from the Langmuir isotherm model for $\mathrm{Cu}$ (II), $\mathrm{Zn}$ (II) and Cd(II) were 52.63, 43.47 and $35.71 \mathrm{mg} / \mathrm{g}$ for Prosopis juliflora seed powder. The values of adsorption affinity ( $\mathrm{b} \mathrm{L} / \mathrm{mg}$ ) were found to be $0.0795,0.0774$ and $0.0933 \mathrm{~L} / \mathrm{mg}(\mathrm{Cu}(\mathrm{II}), \mathrm{Zn}(\mathrm{II})$ and $\mathrm{Cd}(\mathrm{II}))$ metal ions.

ADSORPTION ISOTHERM PARAMETERS FOR THE ADSORPTION OF Cd, Cu AND Zn ON Prosopis juliflora SEED

\begin{tabular}{ccccc|ccc}
\hline \multirow{2}{*}{ Adsorbent } & \multirow{2}{*}{ Metal ions } & \multicolumn{3}{c|}{ Freundlich isotherm } & \multicolumn{3}{c}{ Langmuir isotherm } \\
\cline { 3 - 8 } & & $\mathrm{K}_{\mathrm{f}}(\mathrm{mg} / \mathrm{g})$ & $\mathrm{n}(\mathrm{L} / \mathrm{mg})$ & $\mathrm{R}^{2}$ & $\mathrm{Q}_{0}(\mathrm{mg} / \mathrm{g})$ & $\mathrm{b}(\mathrm{L} / \mathrm{mg})$ & 0.0795 \\
\hline Prosopis & $\mathrm{Cd}(\mathrm{II})$ & 4.99 & 1.57 & 0.989 & 52.63 & 0.997 \\
juliflora & $\mathrm{Cu}(\mathrm{II})$ & 4.24 & 1.61 & 0.974 & 43.47 & 0.0774 & 0.995 \\
powder & $\mathrm{Zn}(\mathrm{II})$ & 4.37 & 1.77 & 0.974 & 35.71 & 0.0933 & 0.998 \\
\hline
\end{tabular}


The stronger affinity of biosorbents towards $\mathrm{Cd}$ (II) than $\mathrm{Cu}$ (II) and $\mathrm{Zn}$ (II) can be related to ionic radius and atomic weight. The $1 / \mathrm{n}$ values calculated from the Freundlich isotherm model (Table-1) lie between 0 and 1 . This suggests that the adsorption of metal ions onto biosorbents was favourable. The adsorption behaviour was further evaluated by separation factor $\left(\mathrm{R}_{\mathrm{L}}\right) . \mathrm{R}_{\mathrm{L}}$ is a dimensionless constant obtained from the Langmuir isotherm model. It can be expressed as:

$$
\mathrm{R}_{\mathrm{L}}=\frac{1}{\left(1+\mathrm{bC}_{0}\right)}
$$

As described by Hall et al. [13], $\mathrm{R}_{\mathrm{L}}$ values indicate the shape of isotherm: (1) unfavourable $\left(R_{L}>1\right)$, (2) linear $\left(R_{L}=1\right)$ and (3) favourable $0<R_{L}<1$ and (4) irreversible $\left(R_{L}=0\right)$. The $R_{L}$ values for $\mathrm{Cu}(\mathrm{II}), \mathrm{Cd}(\mathrm{II})$ and $\mathrm{Zn}(\mathrm{II})$ adsorption by Prosopis juliflora seed were in the range $0<\mathrm{R}_{\mathrm{L}}<1$. This indicates that the adsorption of metal ions was favourable. The maximum adsorption capacity (Q) of Prosopis juliflora seed for $\mathrm{Cu}(\mathrm{II})$, $\mathrm{Cd}$ (II) and Zn(II) were compared with other low-cost adsorbents. From Table-2, it is apparent that the adsorption capacity of biosorbents studied was comparable with other adsorbents. The difference in metal uptake by various adsorbents may be due to the difference in physical and chemical characteristics of the adsorbents [4].

TABLE-2

COMPARISON OF ADSORBENT CAPACITY OF VARIOUS LOW COST ADSORBENTS FOR THE ADSORPTION OF $\mathrm{Cd}, \mathrm{Cu}$ AND Zn METAL IONS IN AQUEOUS SOLUTION

\begin{tabular}{lcccc}
\hline \multirow{2}{*}{ Adsorbents } & \multicolumn{3}{c}{$\mathrm{Q}(\mathrm{mg} / \mathrm{g})$} & \multirow{2}{*}{ Ref. } \\
\cline { 2 - 4 } & $\mathrm{Cd}$ & $\mathrm{Cu}$ & $\mathrm{Zn}$ & \\
\hline Moringa oleifera & 90.25 & 39.52 & 72.99 & {$[14]$} \\
Musa cavendish & 32.6 & 28.57 & - & {$[15,16]$} \\
Black gram husk & 39.99 & 25.73 & 33.81 & {$[17]$} \\
Rise husk & 8.58 & 30.30 & - & {$[18]$} \\
Sunflower stalk & 42.18 & 29.30 & 30.73 & {$[19]$} \\
\hline
\end{tabular}

\section{Conclusion}

Prosopsis juliflora seed powder is a economically feasible and low cost adsorbent for the removal of $\mathrm{Cd}(\mathrm{II}), \mathrm{Cu}(\mathrm{II})$ and $\mathrm{Zn}$ (II) ions from aqueous solution. $\mathrm{Cd}(\mathrm{II}), \mathrm{Cu}$ (II) and $\mathrm{Zn}$ (II) adsorption onto Prosopsis juliflora seed powder shows high association with Langmuir and Freundlich isotherm model. Correlation coefficient values indicates the adsorption process most fit to Langmuir model. The $1.0 \mathrm{mg}$ of Prosopsis juliflora can absorb 52.63, 43.47 and $35.71 \mathrm{mg} / \mathrm{g}$ of $\mathrm{Cd}(\mathrm{II}), \mathrm{Cu}(\mathrm{II})$ and $\mathrm{Zn}$ (II) in a favourable condition. This study can conclude that the Prosopsis juliflora seed powder is the favourable alternative of $\mathrm{Cd}(\mathrm{II}), \mathrm{Cu}$ (II) and $\mathrm{Zn}$ (II) removal from aqueous solution.

\section{CONFLICT OF INTEREST}

The authors declare that there is no conflict of interests regarding the publication of this article.

\section{REFERENCES}

1. O.B. Akpor, G.O. Ohiobor and T.D. Olaolu, Adv. Biosci. Bioeng., 2, 37 (2014);

https://doi.org/10.11648/j.abb.20140204.11.

2. K.S. Bharathi and S.T. Ramesh, Appl. Water Sci., 3, 773 (2013); https://doi.org/10.1007/s13201-013-0117-y.

3. A.M. And and I. Alli, J. Sci. Agric., 44, 99 (1988); https://doi.org/10.1002/jsfa.2740440202.

4. A. Dubey and S. Shiwani, Int. J. Environ. Sci. Technol., 9, 15 (2012); https://doi.org/10.1007/s13762-011-0012-8.

5. S.N.M. Yusoff, A. Kamari, W.P. Putra, C.F. Ishak, A. Mohamed, N. Hashim and I.M. Isa, J. Environ. Prot., 5, 289 (2014); https://doi.org/10.4236/jep.2014.54032.

6. V. Sangu and K. Kannan, Indian J. Chem. Technol., 24, 644 (2017).

7. J. Salehzadeh, Leonardo J. Sci., 23, 97 (2013).

8. V. Sangu, K. Kannan and K. Srinivasan, Asian J. Chem., 26, 6131 (2014); https://doi.org/10.14233/ajchem.2014.16845.

9. N. Suganthi and K. Srinivasan, Indian J. Eng. Mater. Sci., 17, 382 (2010).

10. I. Langmuir, J. Am. Chem. Soc., 40, 1361 (1918); https://doi.org/10.1021/ja02242a004.

11. G. McKay, H.S. Blair and J.R. Gardner, J. Appl. Polym. Sci., 27, 3043 (1982); https://doi.org/10.1002/app.1982.070270827.

12. M.B. Desta, J. Thermodyn., 2013, 1 (2013); https://doi.org/10.1155/2013/375830.

13. K.R. Hall, L.C. Eagleton, A. Acrivos and T. Vermeulen, Ind. Eng. Chem. Fundam., 5, 212 (1966); https://doi.org/10.1021/i160018a011.

14. I.W. Maina, V. Obuseng and F. Nareetsile, J. Chem., 2016, 1 (2016); https://doi.org/10.1155/2016/9312952.

15. M. Shaikh, Int. J. Interdisc. Innov. Res. Develop., 4, 55 (2017).

16. N.A.A. Aziz, N. Jayasuriya and L. Fan, IOP Conf. Series: Mater. Sci. Eng., 136, 12044 (2016); https://doi.org/10.1088/1757-899X/136/1/012044.

17. A. Saeed, M. Iqbal and M.W. Akhtar, J. Hazard. Mater., 117, 65 (2005); https://doi.org/10.1016/j.jhazmat.2004.09.008.

18. D.S. Malik, C.K. Jain and A.K. Yadav, Appl. Water Sci., 7, 2113 (2017); https://doi.org/10.1007/s13201-016-0401-8.

19. G. Sun and W. Shi, Ind. Eng. Chem. Res., 37, 1324 (1998); https://doi.org/10.1021/ie970468j. 